\title{
Effects of Oral and Topical Momordica Charantia-Propolis Premix on Wound Healing
}

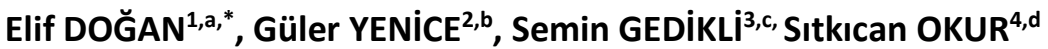

\begin{abstract}
${ }^{1}$ Kastamonu University' Faculty of Veterinary Medicine, Department of Surgery, Kastamonu, Turkey
${ }^{2}$ Atatürk University, Faculty of Veterinary Medicine' Department of Animal Nutrition and Nutritional Disease, Erzurum, Turkey

${ }^{3}$ Atatürk University' Faculty of Veterinary Medicine' Department of Histology and Embryology, Erzurum, Turkey

${ }^{4}$ Atatürk University' Faculty of Veterinary Medicine, Department of Surgery, Erzurum, Turkey

aORCID: 0000-0002-3321-8116, bORCID: 0000-0003-0819-8843, 'ORCID: 0000-0001-8238-7226, dORCID: 0000-0003-2620-
\end{abstract}

$897 X$

Tarihi: 16.03.2020

Kabul Tarihi: 17.06.2020

Abstract: Momordica charantia and Propolis (MCP) are reported to have antibacterial, antifungal, antioxidant and antiinflammatory properties. The present study determines the efficacy of the oral and topical administration of MCP on wound healing in 60 adult male rats. The wounds in the control rats were left untreated, the rats in the MCP-oral group were treated with oral MCP, and the animals in the MCP-topical group were treated by pouring MCP powder onto the wound. The wound size was measured on the 3rd, 7th, 14th and 21st days, and tissue specimens were taken from five animals in both groups. The tissue samples were evaluated histopathologically. Remission following treatment during the follow-up period was described as a percentage of the original wound size for each rat. A two-way ANOVA was used for the analysis of data. The mean wound surface area was measured as $1.69 \mathrm{~cm}^{2}$. At the end of the experiment, the average reduction was $81.40 \%$ in MCP-topically and $87.85 \%$ in MCP-orally treated wounds. The lowest decrease in wound size was measured in the control group ( $45.55 \%$ ). Wound size reduction was not significantly different between the MCP groups at the end of the experiment. Re-epithelialization and neovascularization were complete in both the MCP-oral and MCPtopical groups up to day 21. Overall, the treatments with oral and topical MCP were equally effective in wound healing. MCP application can be considered for the acceleration of wound healing, in both oral and topical administrations. Keywords: Momordica charantia, Propolis, Rat, Wound healing.

\section{Momordica Charantia-Propolis Premiksinin Yara lyileşmesinde Oral ve Topikal Etkileri}

Özet: Momordica charantia ve Propolis'in (MCP) antibakteriyel, antifungal, antioksidan ve antienflamatuar özelliklere sahip olduğu bildirilmektedir. Bu çalışmada, 60 yetişkin erkek sıçanda MCP'nin oral ve topikal uygulanmasının yara iyileşmesi üzerindeki etkinliğinin belirlenmesi amaçlanmıştır. Çalışmada kontrol sıçanlarındaki yaralar tedavi edilmeden bırakıldı, MCPoral gruptaki sıçanlar oral MCP ile tedavi edildi ve MCP topikal grubundaki hayvanlar, yara üzerine MCP tozu dökülerek tedavi edildi. Yara boyutu 3., 7., 14. ve 21. günlerde ölçüldü ve her iki gruptaki beş hayvandan doku örnekleri alındı. Doku örnekleri histopatolojik olarak değerlendirildi. Takip süresi boyunca tedaviyi takiben remisyon, her sıçan için orijinal yara boyutunun yüzdesi olarak tanımlandı. Verilerin analizi için iki yönlü bir ANOVA kullanıldı. Ortalama yara yüzey alanı $1.69 \mathrm{~cm}^{2}$ olarak ölçüldü. Deneyin sonunda ortalama azalma MCP-topikal grubunda \%81.40 ve MCP-oral grubundaki yaralarda\%87.85 idi. Yara boyutundaki en düşük azalma kontrol grubunda (\%45.55) ölçüldü. Yara boyutundaki küçülme, deney sonunda MCP grupları arasında önemli ölçüde farklı değildi. 21. güne kadar hem MCP-oral hem de MCP-topikal gruplarda yeniden epitelizasyon ve neovaskülarizasyon tamamlandı. Genel olarak, oral ve topikal MCP ile yapılan tedaviler yara iyileşmesinde eşit derecede etkilidir. Momordica charantia ve Propolis'in hem oral hem de topikal uygulamaları yara iyileşmesinin hızlandırılması için düşünülebilir.

Anahtar Kelimeler: Momordica charantia, Propolis Rat, Yara iyileşmesi.

\section{Introduction}

Wound healing is a process that includes hemostasis, inflammation, proliferation and maturation. The effects of various substances as an aid to tissue repair has been a subject of research for many years. Factors such as age, nutrition, radiation, medicine, hypertension, diabetes and obesity delay wound healing (Diegelmann, 2004). Although many drugs are used for the treatment of wounds, allergic reactions and the cost of medications are factors that limit their use (Kim, 2017). Momordica charantia (MC) is a plant that is widely used in many countries as both a food ingredient and for its medicinal properties (Das, 2015; Sahu, 2011), having anti-diabetic, antibacterial, anti-oxidant, anti-inflammatory, antiulcer, anti- fungal, anti-depressant and analgesic uses (Ahmad, 2012; Sahu, 2011; Zhang, 1992). It accelerates the regeneration process and tissue 
healing by producing growth factors and increasing fibroblastic activity (Ono, 2009). According to several experimental studies (Sankaranarayanan, 1993; Singh, 2017), the application of a MC powder to a wound area increases wound contraction, accelerates wound healing, shortens the epithelization period, improves stress resistance and hastens wound regeneration. Momordica charantia is frequently used for the topical treatment of skin wounds and orally for treatment of disease such as gastric ulcers and diabetes (Grover, 2004).

Propolis, which is thought to accelerate wound healing, is a resinous material that is collected from plants by honeybees (Basim, 2006). In recent years, propolis has come to be considered as a complementary drug due to its therapeutic properties, and has been the subject of comprehensive researches. Many components have been identified in the chemical composition of propolis, such as polyphenols, flavonoids, serpens quinones, coumaric acid, amino acids, steroids and inorganic compounds. Propolis has various biological properties, being antibacterial (Keskin, 2001) antifungal (Koç, 2005), antioxidant (Simões, 2004), anti-inflammatory (Miyataka, 1997) and immune-system stimulating (Gu, 2005). Propolis has generally been applied topically to skin wounds by researchers (Atayoglu, 2016; Ragab, 2015). Since topical propolis has high potential for wound healing, it can accelerate the healing process by reducing the number of mast cells (Wang, 2008). The use of topical drugs is described as the direct application of a drug to the skin for the treatment of skin damage. Topical drugs offer some advantages, such as the absence of a first pass metabolism, the absence of gastrointestinal inadaptability and the more precise application to a specific site (Sıngla, 2012). If animals feel uncomfortable, however, any bandage applied after a topical application should be removed (Anderson, 2000). As animals may aggravate the wound area among the various drug delivery routes, the oral route may be more advantageous. Studies have reported that $M C$ is always used topically on wounds and orally for other diseases (Ahmad, 2012; Sahu, 2011; Zhang, 1992). Propolis is already in use topically in wound cases (Atayoglu, 2016; Ragab, 2015). A review of literature identified no scientific investigation to date conducted of the effect of oral administration of this premix on wound healing. The present study aims to compare the efficacy of the oral and topical administration of MCP on excision wounds.

\section{Material and Methods}

The animal experiments were performed after gaining approval from the Ethical Committee (decision no: 2018/38) Atatürk University, Erzurum, Turkey. Six months old, male, Sprague-Dawley rats ( $N=60$ ) weighing 350-400 g were used for the study. Rat chow and tap water were given ad

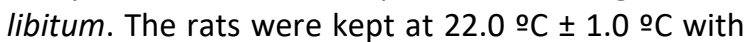
12 hours per day of light. The experimental rats were divided randomly into three groups containing twenty rats each, named the control, treatment orally and treatment topically groups.

Xylazine $\mathrm{HCl}(8 \mathrm{mg} / \mathrm{kg}$, Xylazinbio $2 \%$, Bioveta, Czech republic) and ketamine $\mathrm{HCl}(60 \mathrm{mg} / \mathrm{kg}$, Ketasol 10\%, Richter pharma, Austria) were used intramuscularly for anesthesia in all animals. The rats were positioned in sternal recumbency and the hair on the back was shaved. After the skin was prepared with $70 \%$ ethanol, one (1) full-thickness excision wound was made to the midline involving the removal of a $1.3 \mathrm{~cm} \times 1.3 \mathrm{~cm}\left(1.69 \mathrm{~cm}^{2}\right)$ section of skin by using punch biopsy.

The wounds in the control group was untreated, while the wounds in the treatment groups were treated topically and orally (250 $\mathrm{mg} / \mathrm{kg}$ ) with MCP (Kudret narı \& Propolis capsule 375 MG*60 capsule, MC $200 \mathrm{mg}$, propolis $100 \mathrm{mg}$, capsule $75 \mathrm{mg}$, Balen, Turkey). MCP capsule was broken and the powder inside the capsule was poured into the wound area in topically groups. In groups orally, this powder was dissolved in $1 \mathrm{ml}$ of saline and administered by gavage. The wounds were protected with a bandage (sterile gauze compress, PAK, Istanbul, Turkey; and adhesive tape, Cansın Plast, Kocaeli, Turkey). The medication was applied daily until the end of study.

The unhealed wound area was measured on the 3rd, 7th, 14th and 21st days under general anesthesia using a transparent paper and a special marker pen (Mahmood, 2010). The wound closure was calculated as percentage reduction from the wound size on day zero using the following formula: (Agren, 1997)

$$
\text { Epithelization }(\%)=\frac{100 \times\left(\text { wound size on } d_{0}-\text { wound size on } d_{x}\right)}{\text { wound size on } d_{0}}
$$

On the 3rd, 7th, 14th and 21st days, the five rats in each group were sacrificed with a lethal dose mixture (Xylazine $\mathrm{HCL}$ and Ketamine $\mathrm{HCL}$ ) and the wounded areas were collected. The tissues collected from the wound sites were fixed in a $10 \%$ neutral formalin solution for 72 hours. Skin specimens were embedded in paraffin wax after xylene and in a graded alcohol series. Sections measuring $5-\mu \mathrm{m}$ thick were cut using a microtome (Leica Microsystems, Wetzlar, Germany) and 
stained with Mallory's triple stain, modified by Crossman (Lemo, 2010). The stained specimens were examined under a light microscope (Nikon Eclipse i50, Tokyo, Japan) using an approximately $4 \times$ objective lens, and photographic images were taken for histological evaluation. The specimens were evaluated and scored for acute inflammatory reaction, thickness of granulation tissue, fibroblast maturation, collagenation, re-epithelialization and neovascularization. The scores were determined as 0 : none, 1: mild, 2: moderate and 3: abundant (Abramov, 2007)

Data collection and analyses. The statistical analysis involved a two-way ANOVA, to assess the effect of treatment. Histopathological scores were reported in median values in a univariate analysis (SPSS version 16.0, Chicago, IL). Values of $P<0.05$ were considered statistically significant (Dogan, 2017)

\section{Results}

Wound size. When the wounds were first created, the surface area measured was $1.69 \mathrm{~cm}^{2}$. The wound size was found to have decreased in all wounds at the end of the study. In the entire sample, the mean percent reduction in wound size compared to the original wound area was $30.33 \% \pm$ 1.51 (range $27.28 \%-33.37 \%$ ), $48.13 \% \pm 1.51$ (range $45.08 \%$ - 51.17\%), $73.73 \% \pm 1.51$ (range $70.68 \%$ $76.77 \%$ ) and $87.40 \% \pm 1.51$ (range $84.35 \%$ $90.44 \%$ ) on days $3,7,14$ and 21 , respectively. Overall, within the 21 days, tissue repair in the MCP-orally group was faster than that in the MCPtopically group, as reflected by the lower reduction in wound size when compared to the original wound size (81.40\% versus $87.85 \%)$. The experimental wounds on the $21^{\text {st }}$ day were more advanced in healing response in the MCP-treated groups $(84.62 \%)$ when compared to the control group (45.55\%) $(P<0.0001)$ (see Table 1$)$.

\begin{tabular}{|c|c|c|}
\hline Effects & $\begin{array}{c}\% \text { reduction in } \\
\text { wound size after } \\
21 \text { days }\end{array}$ & $P>F$ \\
\hline Treatment & & 0.0001 \\
\hline Untreated & $45.55 \pm 1.31^{b}$ & \\
\hline MCP-oral & $87.85 \pm 1.31^{a}$ & \\
\hline MCP-topical & $81.40 \pm 1.31^{a}$ & \\
\hline Day & & 0.0001 \\
\hline 3 & $30.33 \pm 1.51^{d}$ & \\
\hline 7 & $48.13 \pm 1.51^{c}$ & \\
\hline 14 & $73.73 \pm 1.51^{b}$ & \\
\hline 21 & $87.40 \pm 1.51^{\mathrm{a}}$ & \\
\hline
\end{tabular}

Wound macroscopy. Mild erythema was observed on the wound edges in the untreated rats and the topical MCP rats on day 3. On day 7 , a thin layer of tissue was observed at the base of the wound in both MCP groups. Wound contraction on day 14 was recorded to be highest in the MCP-orally treated wounds, followed by the MCP-topically and untreated wounds. On day 21, the highest wound contraction was noted in the topical MCP group (see figure 1).

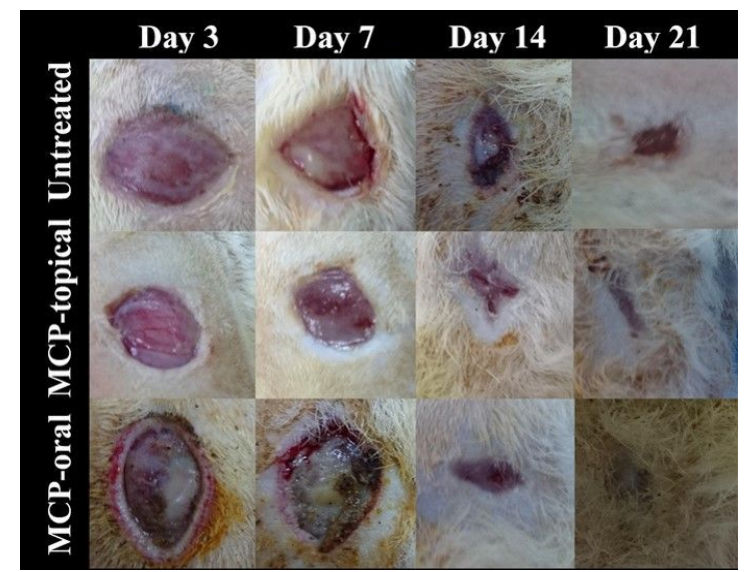

Figure 1. Macroscopy images of wounds in rats

\section{Histopathology}

Quantitative microscopy. Overall, more prominent necrotic areas, lymph follicles and dense hemorrhagic areas were detected in the control group. Acute inflammatory reaction scores were higher in the control and MCP oral groups than MCP topical group on the 14 th day (1.00 versus 0.00$)$, though acute inflammatory reaction was not observed in all groups at the end of the study. On day 21 , the amount of collagen was found to have increased in both MCP groups (1.00 versus 2.00).

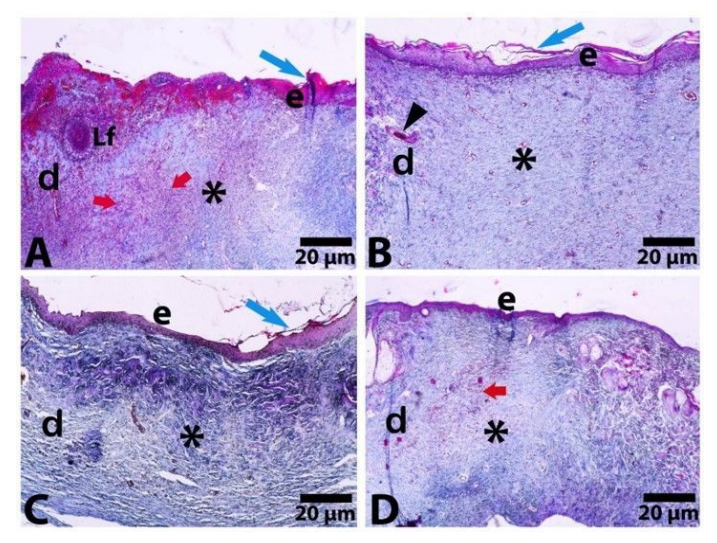

Figure 2. Microscopy images of wounds in rats at the end of the study. 
On the 14th day, granulation tissue was determined as the highest score (score of 2 ) in all three groups. However, on 21 days, while the score was 1 in the MCP-orally and control groups, it was 0 in MCP-topically group. Fibroblast maturation (median score of 1 ) was observed on day 3 in the MCP-orally group and on day 7 in the MCP-topically group. Neovascularization had increased in both the MCP groups by the end of the study period ( 1.00 versus 3.00). Reepithelization was prominent in the MCP-orally group on day 3, while full reepithelialization and neovascularization was recorded in both the MCP groups by the end of the study (median score of 3) (see Table 2). In general, when the MCP treatments are compared with the untreated control wounds, equally effective histopathological parameters were reported in both MCP groups at the end of the study. (see Figure 2 ).

\section{Discussion}

Wound healing is a basic response to tissue damage. Although there have been many studies of this subject, the best curative agent is still under discussion. Although the wound healing process has improved, studies have reported that healing times have not been shortened (Pillai, 2010). The main approach to wound healing should involve the prevention if the invasion of damaged tissue by microorganisms, and improving the damaged tissue, for which many medical products have been used. Propolis, or bee glue, is used primarily for the therapeutic treatment of wounds and burns (Oryan, 2018), and MC is used to achieve the same effect. The efficacy of the topical use of these on wounds has been studied (Hussan, 2014; Ragab, 2015). No

Table 2. Median histopathological evaluation scores of wounded tissue by treatment group.

\begin{tabular}{lcccccc}
\hline Effects & $\begin{array}{c}\text { Acute } \\
\text { Inflammatory } \\
\text { reaction }\end{array}$ & $\begin{array}{c}\text { Granulation } \\
\text { tissue }\end{array}$ & $\begin{array}{c}\text { Fibroblast } \\
\text { maturation }\end{array}$ & Collagenation & $\begin{array}{c}\text { Re- } \\
\text { epithelization }\end{array}$ & $\begin{array}{c}\text { Neo- } \\
\text { vascularization }\end{array}$ \\
\hline Treatment & $1.50^{\mathrm{a}}$ & 1.00 & 1.50 & $1.00^{\mathrm{b}}$ & $1.00^{\mathrm{c}}$ & $1.00^{\mathrm{b}}$ \\
Untreated & $1.50^{\mathrm{a}}$ & 1.00 & 1.50 & $1.50^{\mathrm{a}}$ & $2.0^{\mathrm{a}}$ & $2.00^{\mathrm{a}}$ \\
MCP-oral & $1.00^{\mathrm{b}}$ & 1.00 & 1.50 & $1.50^{\mathrm{a}}$ & $1.50^{\mathrm{b}}$ & $2.00^{\mathrm{a}}$ \\
MCP-topical & & & & & & \\
\hline Day & $3.0^{\mathrm{a}}$ & $0.5^{\mathrm{c}}$ & $0.5^{\mathrm{c}}$ & $0.5^{\mathrm{c}}$ & $0^{\mathrm{d}}$ & $1.0^{\mathrm{d}}$ \\
3 & $2.0^{\mathrm{b}}$ & $1.5^{\mathrm{b}}$ & $1.0^{\mathrm{b}}$ & $1.0^{\mathrm{b}}$ & $1^{\mathrm{c}}$ & $1.5^{\mathrm{c}}$ \\
7 & $0^{\mathrm{c}}$ & $2.0^{\mathrm{a}}$ & $2.0^{\mathrm{a}}$ & $2.0^{\mathrm{a}}$ & $2.0^{\mathrm{b}}$ & $2.0^{\mathrm{b}}$ \\
14 & $0^{\mathrm{c}}$ & $0.5^{\mathrm{c}}$ & $2.0^{\mathrm{a}}$ & $2.0^{\mathrm{a}}$ & $2.5^{\mathrm{a}}$ & $2.5^{\mathrm{a}}$ \\
\hline
\end{tabular}

The scores ${ }^{26}$ were $0=$ none, $1=$ mild, $2=$ moderate, and $3=$ abundant.

${ }^{a-d}$ indicates statistical different among rows with the main effect categories $(P<0.05)$.

studies reporting on the use of this premix (MC and propolis) were identified in a review of literature. In this study, MCP was administered both orally and topically to compare its efficacy on wound healing. Oral and topical use were compared in the present study due to the lack of studies into the oral administration of MCP for wound treatment in literature.

Various medicinal plants have been used to promote wound healing (Kim, 2011). The use of such products has increased significantly in recent years in animals. Among such substances, propolis is a resinous material collected by honeybees from living plants, while $\mathrm{MC}$ is a type of creeper plant, and both are known to be strong antioxidants, antiinflammatories and antibacterial. Studies of wound healing have reported the success of these substances on wound healing processes as a result of their wound healing effects (Atayoglu, 2016; Hussan, 2014). In present study, the epithelization percentage was considered a clinical healing parameter. The epithelialization rate was calculated to be approximately $70 \%$ within 3 weeks in both MCP groups, but did not reach $100 \%$ in either of the MCP-group rats. Wounds treated with MCP-topical reached a greater percent contraction than the
MCP- orally group. It has been reported that wound contraction is very important in clinical evaluations of wound healing (Oryan, 2018). In this study, in both the MCP-orally and MCP- topically groups, there was no significant difference in the contraction rate of the wounds, and also in this study, histopathological parameters explained the changes in the wound site. The acute inflammatory reaction score on the 3rd day following wound creation may indicate the success of wound induction. The absence of any chronic inflammation at the end of the study may indicate that 21 days is a sufficient follow-up period. In parallel, it is reported that proliferation, granulation and contraction occur between 4-21 days in the wound healing process (Keast, 2000).

Throughout the study, the increased collagenation, fibroblast maturation, granulation tissue amount, neovascularization and reepithelization scores noted in reply to medication were prominent in wound healing. Collagen tissue plays important roles in all stages of wound healing. Tissue synthesized by fibroblasts is particularly active in the proliferative and remodeling phases, and forms the basis of the intracellular matrix formation (Baum, 2005). In the present study, it was 
observed that this parameter increased in MCP groups up until the end of the experiment. As collagen synthesis begins on day 3 in injured tissue (Ramos, 2007), the histopathological findings on the third day were compared. While no collagen tissue was observed in the control group, it was observed at level 1 in the MCP groups. In a wound healing process, fibroblasts secrete an extracellular matrix that joins the edges of the wound (Otranto, 2010). This stage can be clinically monitored in terms of granulation tissue formation (Velnar, 2009), however, fibroblast maturation and the formation of granulation tissue between the MCP-oral and MCP-topical treatment groups were not statistically significant. Re-epithelialization is required for complete closure of the wound (Otranto, 2010). In the present study, it was high score in MCP groups than in the control group, however, both of $\mathrm{MCP}$ groups were not significant each other.

In conclusion, the clinical and histological effects of the oral and topical administration of MCP in wounds inflicted on healthy rats were compared with control wounds. Our findings suggest that an MCP premix may be useful in wound healing. In the MCP groups, the level of reduction of wound size when compared to the untreated group showed a statistically significant difference, while no statistically significant difference was noted between the MCP-oral and MCP-topical groups. Histopathological changes such as inflammatory reaction, granulation tissue formation, collagenation, fibroblast maturation, reepithelization and neovascularization scores were similar in the MCP-oral and MCP-topical treatment groups. Oxidative stress must be determined in acute and chronic inflammatory conditions such as wound healing and degenerative processes. Accordingly, to further examine the potential effect of MCP on wound repair in different laboratory animals, future studies should take into account blood and tissue chemistry variables and should associate any changes with oxidative status and tissue regeneration ability.

\section{References}

Abramov Y, Golden B, Sullivan M, Botros SM, Miller JJR et al, 2007: Histologic characterization of vaginal vs. abdominal surgical wound healing in a rabbit model. Wound Repair Regen, 15 (1), 80-86.

Agren MS, Mertz PM, Franzen, L, 1997: Acomparative study of three occtusive dressing in the treatment of full thickness wounds in pigs. J Am Acad Dermatol, 36, 53-58.

Ahmad Z, Zamhuri KF, Yaacob A, Siong CH, Selvarajah M et al, 2012: In vitro anti-diabetic activities and chemical analysis of polypeptide-k and oil isolated from seeds of Momordica charantia (bitter gourd). Molecules, 17(8), 9631-9640.

Anderson DM, White RAS, 2000: Ischemic bandage injuries: A case series and review of the literature. Vet Surg, 29(6), 488-498.

Atayoglu AT, Silıcı S, 2016: Preliminary Study on Wound Healing Activity of Propolis in Albino Rats. International Journal of Innovative Research in Medical Sciences, 1(7), 2455-8737.

Basim E, Basim H, Özcan M, 2006: Antibacterial activities of Turkish pollen and propolis extracts against plant bacterial pathogens. J Food Eng , 77(4), 992-996.

Baum CL, Arpey CJ, 2005: Normal cutaneous wound healing: clinical correlation with cellular and molecular events. Dermatol Surg, 31, 674-686.

Das DR, Sachan AK, Imtiyaz M, Shuaib M, 2015: Momordica charantia as a potential medicinal herb: an overview. J. Med. Plants Stud, 23(25), 23-26.

Diegelmann RF, Evans MC, 2004: Wound healing: an overview of acute, fibrotic and delayed healing. Front in Biosci, 9(1), 283-289.

Grover JK, Yadav SP, 2004: Pharmacological actions and potential uses of Momordica charantia: a review. $J$ Ethnopharmacol, 93, 123-132.

Gu Y, Kaida T, Kaida K, 2005: Immunostimulating and Antitumor Effects by Inonotus obliquus (Ach.:Pers.) Pilat. Int J Med Mushrooms, 7(3), 406.

Hussan F, Teoh SL, Muhamad N, Mazlan M, Latiff AA, 2014: Momordica charantia ointment accelerates diabetic wound healing and enhances transforming growth factor- $\beta$ expression. J Wound Care, 23(8), 400-407.

Keast D. Ve Orsted H, 2000: The basic principles of wound healing. Ostomy Wound Manag, 46(11), 16.

Keskin N, Hazır S, Baser KHC, Kurkcuoglu M, 2001: Antibacterial activity and chemical composition of Turkish propolis. Z Naturforsch, 56(11-12), 11121115.

Kim J, Lee CM, 2017: Wound healing potential of a polyvinyl alcohol-blended pectin hydrogel containing Hippophae rahmnoides L. extract in a rat model. Int J Biol Macromol, 99, 586-593.

Kim YS, Cho IH, Jeong MJ, Jeong SJ, Nah SY et al, 2011: Therapeutic effect of total ginseng saponin on skin wound healing. J Ginseng Res, 35(3), 360-367.

Koc AN, Silici S, Ayangil D, Ferahbaş A, Çankaya S, 2005: Comparison of in vitro activities of antifungal drugs and ethanolic extract of propolis against Trichophyton rubrum and T.mentagrophytes by using a microdilution assay. Mycoses, 48(3), 205210.

Lemo N, Marignac G, Reyes-Gomez E, Lilin T, Crosaz O et al, 2010: Cutaneous reepithelialization and wound contraction after utaneous reepithelialization and wound contraction after skin biopsies in rabbits: a mathematical model for healing and kin biopsies in rabbits: a mathematical model for healing and remodelling index. Vet Arh, 80(5), 637-652.

Mahmood AA, Mariod AA, Abdelwahab SI, Ismail S, AlBayaty F, 2010: Potential activity of ethanolic extract of Boesenbergia rotunda (L.) rhizomes extract in accelerating wound healing in rats. $J$ Med Plant Res, 4(15), 1570-1576. 
Miyataka $H$, Nishiki $M$, Matsumoto $H$, Fujimoto $T$, Matsuka $\mathrm{M}$ et al, 1997: Evaluation of propolis. Part I: evaluation of Brazilian and Chinese propolis by enzymatic and phsico- chemical methods. Biol Pharm Bull, 20(5), 496-501.

Ono T, Tsuji T, Sakai M, Yukizaki C, Ino $\mathrm{H}$ et al, 2009: Induction of hepatocyte growth factor production in human dermal fibroblasts and their proliferation by the extract of bitter melon pulp. Cytokine,46(1), 119-126.

Oryan A, Alemzadeh E, Moshiri A, 2018: Potential role of propolis in wound healing: Biological properties and therapeutic activities. Biomed Pharmacother, 98, 469-483.

Otranto M, Do Nascimento AP, Monte-Alto-Costa A, 2010: Effects of supplementation with different edible oils on cutaneous wound healing. Wound Repair Regen, 18(6), 629-636.

Pillai SI, Palsamy P, Subramanian S, Kandaswamy M, 2010: Wound healing properties of Indian propolis studied on excision wound-induced rats. Pharm Biol, 48(11), 1198-1206.

Ragab Al, Mekkawy MM, El-Gamil A, Mohanny KM, 2015: Effect of Propolis Dressing Technique on the Healing of Septic Diabetic Foot Ulcers. IOSR Journal of Nursing and Health Science (IOSR-JNHS4), 4, 33-52.

Ramos AFN, Miranda JL. 2007: Propolis: a review of its anti-inflammatory and healing actions. J Venom Anim Toxins Incl Trop Dis,13(4), 697-710.

Sahu RK, Jain A, Nayak S. 2011: Momordica charantia Linn.: a mini review. Int J Biomed Res, 11 (2), 579587.
Sankaranarayanan J, Jolly Cl, 1993: Phytochemical, antibacterial and pharmacological investigations on Momordica charantia Linn. Emblica officinalis gaertn. and Curcuma longa Linn. Indian JPharm Sci, 55(1), 6-13.

Sıngla V, Saını A, Joshı B, Rana AC, 2012: Emulgel: A new platform for topical drug delivery. Int J Pharma Bio Sci, 3(1), 485-498.

Simões LMC, Gregório LE, Da Silva Filho AA, de Souza ML, Azzolini AECS et al, 2004: Effect of Brazilian green propolis on the production of reactive oxygen species by stimulated neutrophils. J Ethnopharmacol, 94(1), 59-65.

Singh R, Garcia-Gomez I, Gudehithlu KP, Singh AK, 2017: Bitter Melon Extract Promotes Granulation Tissue Growth and Angiogenesis in the Diabetic Wound. Adv Skin Wound Care, 30(1), 16-26.

Velnar T, Baıley T, Smrkolj V, 2009: The wound healing process: an overwiev of the cellular and molecular mechanisms. J. Int. Med. Res., 37: 1528-1542.

Wang, L. Chen, W. Wu, Y. Long, R. Wang, 2008: Potential cytoprotection: antioxidant defence by caffeic acid phenethyl ester against free radical-induced damage of lipids, DNA, and proteins. Can J Physiol Pharmacol, 86 (5), 279-287.

Zhang QC, 1992: Preliminary report on the use of Momordica charantia extract by HIV patients. IntJNM, 3, 65-69.

\section{*Corresponding author: Elif DOĞAN}

Kastamonu University, Faculty of Veterinary Medicine, Department of Surgery, Kastamonu, Turkey. e-mail: elifdogan@kastamonu.edu.tr 